\title{
Correlation of proline content and gene expression involved in the metabolism of this amino acid under abiotic stress
}

\author{
Letícia Carvalho Benitez ${ }^{1}$ Isabel Lopes Vighi ${ }^{1} \cdot$ Priscila Ariane Auler $^{1}$. \\ Marcelo Nogueira do Amaral ${ }^{1} \cdot$ Gabriela Peres Moraes ${ }^{1}$. \\ Gabriela dos Santos Rodrigues ${ }^{1}$ - Luciano Carlos da Maia ${ }^{2}$ • \\ Ariano Martins de Magalhães Júnior ${ }^{3} \cdot$ Eugenia Jacira Bolacel Braga $^{1}$
}

Received: 29 January 2016/Revised: 20 October 2016/Accepted: 25 October 2016/Published online: 31 October 2016

(C) Franciszek Górski Institute of Plant Physiology, Polish Academy of Sciences, Kraków 2016

\begin{abstract}
This study evaluated the metabolism of proline in rice based on the expression pattern of genes involved in biosynthesis and catabolism of amino acid and determined the correlation with the proline content produced under stress. In stage V4, genotypes with a differentiated response to salinity and low-temperature stresses were exposed separately to two test conditions: $150 \mathrm{mM} \mathrm{NaCl}$ and $13{ }^{\circ} \mathrm{C}$. Proline increased in both genotypes and stresses. The expression of P5CS1 was increased in both genotypes and conditions, while P5CS2 was responsive in the sensitive genotype under salinity. High correlations between proline content/P5CS1, proline content/P5CS2, P5CS1/P5CR, and P5CS2/P5CR were observed for the tolerant genotype under salt stress. The correlation between proline content $/ P D H$ was 0.42 and -0.13 (tolerant genotype) and -0.54 and 0.15 (sensitive genotype) under salinity and cold, respectively. $\mathrm{P} 5 \mathrm{CDH}$ was positively correlated with proline content under salinity for both genotypes. Under salt stress, there was a positive correlation between proline content/OAT in the tolerant genotype. It was concluded that the increase in proline content is greater for the tolerant genotype. Under salt stress, the levels of transcript genes are more correlated with the
\end{abstract}

Communicated by L. A. Kleczkowski.

Letícia Carvalho Benitez

lecbenitez@gmail.com

1 Departamento de Botânica, Universidade Federal de Pelotas, Pelotas, RS, Brazil

2 Departamento de Fitotecnia, Universidade Federal de Pelotas, Pelotas, RS, Brazil

3 Empresa Brasileira de Pesquisa Agropecuária-Estação Experimental Terras Baixas, Pelotas, RS, Brazil proline content in the tolerant genotype, while at $13{ }^{\circ} \mathrm{C}$, the correlation of the sensitive genotype was higher.

Keywords Oryza sativa L. - Abiotic stress ·

Osmotic adjustment $\cdot$ RT-qPCR

\section{Introduction}

The response of plants to abiotic stress is of great interest for research, and genotypes with higher yields in harsh environments are constantly being sought (Monteiro et al. 2014). When grown under stress, the plants are affected by metabolic and physiological damages harmful to their full growth and development (Qin et al. 2015). Thus, studies dealing with this matter are necessary for a better understanding of the adaptation mechanisms of plants to unfavorable environments of cultivation, which, due to constant climate change, are increasingly common (Fariduddin et al. 2013).

Drought, high salinity, and low temperature are some of the environmental conditions with adverse effects on the productivity of most crops, which is particularly true for rice (Oryza sativa L.) (Yamaguchi-Shinozaki and Shinozaki 2006). Salt stress inhibits the growth and development of plants causing: osmotic stress due to the reduction in water availability; ion toxicity, by sodium accumulation and nutritional imbalance; and oxidative stress, by the formation of reactive oxygen species and hormonal imbalance (Silva-Ortega et al. 2008). Cold stress is a problem that affects rice plants in 25 countries, with negative effects on productivity (Cruz et al. 2013). Low temperatures cause chlorosis, necrosis, changes in chlorophyll and fluorescence contents, and changes in the lipid structure and composition of the cell membrane, aside from 
increasing the levels of reactive oxygen species (ROS) and of malondialdehyde (MDA), causing oxidative cell damage (Theocharis et al. 2012). Aside from the above-mentioned effects, both stresses, salinity and cold, cause osmotic stress, causing the plants to trigger the osmotic adjustment to maintain the water, turgor, and cell homeostasis potential.

Osmotic adjustment is a physiological mechanism established by the accumulation of compatible solutes, such as proline, glycine betaine, trehalose, and sucrose in the vacuole or the cytosol. This contributes to the maintenance of the water balance and preservation of the integrity of proteins, enzymes, and cell membranes under stress (Ashraf et al. 2011; Marijuan and Bosch 2013). The amino-acid proline is the most studied compatible solute because of its sensitive response to adverse conditions, such as salinity, drought, and cold (Ashraf et al. 2011; Verbruggen and Hermans 2008).

In plants, proline is synthesized from two routes: the route of glutamate and route of ornithine. As part of the glutamate pathway, the enzymes pyrroline-5-carboxylate synthetase (P5CS) and P5C reductase (P5CR; EC 1.5.1.2) reduce the glutamate to semialdehyde glutamate and sequentially pyrroline-5-carboxylate (P5C) to proline, respectively (Szabados and Savouré 2010). Proline biosynthesis generally occurs constitutively in the cytosol, and is controlled by gene P5CS2. On the other hand, under stress, proline biosynthesis is increased in the chloroplasts and is controlled mainly by gene P5CS1 (Székely et al. 2008). Alternatively, proline can be synthesized from ornithine, which is transaminated by delta-ornithine aminotransferase (OAT) (Szabados and Savouré 2010).

In contrast, the proline catabolism occurs in the mitochondria by the catalytic action of enzymes proline dehydrogenase (PDH; EC 1.5.99.8) which, in most species, is encoded by two genes and 1-pyrroline-5-carboxylate dehydrogenase (P5CDH; EC 1.5.1.12), which converts P5C to glutamate (Ribarits et al. 2007).

According to Xue et al. (2009), proline production is activated and its catabolism repressed during stress. Once the ideal condition is reestablished, the opposite regulation is triggered. However, in some species, data do not always indicate a positive correlation between proline accumulation and adaptation to stress. Some authors suggest that proline accumulation may be related to the tolerance degree, while others claimed that the accumulation of this amino acid is a "symptom" of the injuries, rather than a tolerance indicator (Hien et al. 2003).

The purpose of this study was to evaluate proline metabolism in rice plants by the expression pattern of genes involved in biosynthesis and catabolism of amino acid and check whether the quantity of transcripts is directly related to the proline content under salinity and low temperature. Although there are several studies on the role of proline in response to abiotic stresses, it is noteworthy that this study addresses the simultaneous expression of all genes involved in the proline pathway, rather than that of single genes.

\section{Materials and methods}

\section{Plant material and stress}

The experiments were carried out with two Brazilian rice genotypes that have a differentiated response to salt and cold stress: BRS Pampa (subspecies indica-sensitive) and BRS Bojuru (subspecies japonica-tolerant).

The seeds were germinated on germitest paper rolls, at $25 \pm 2{ }^{\circ} \mathrm{C}$ for 10 days, in an air-conditioned growth chamber. To simulate salt stress, the seedlings were transferred to a greenhouse at $28 \pm 2{ }^{\circ} \mathrm{C}$ in a floating hydroponic cultivation system with trays containing $20 \mathrm{~L}$ of nutrient solution of Yoshida et al. (1976). Per genotype, three trays with 50 seedlings were grown until the plants had four leaves (stage V4). Thereafter, $150 \mathrm{mM} \mathrm{NaCl}$ was added to the nutritive solution, as proposed by Singh et al. (2010), and maintained under these conditions for $72 \mathrm{~h}$ for data collection.

For low-temperature stress, the seedlings were transferred to plastic trays $(3 \mathrm{~L})$ containing commercial soil fertilized as recommended for irrigated rice. Per genotype, three trays with 50 seedlings were used, which were placed in a greenhouse at $28 \pm 2{ }^{\circ} \mathrm{C}$ and irrigated with nutrient solution Yoshida et al. (1976) until the plants had grown four leaves (stage V4). Thereafter, the plants of the control treatment were harvested and the remaining trays placed in a growth at $13{ }^{\circ} \mathrm{C}$ for $72 \mathrm{~h}$ for data collection.

The collection of material for analysis (leaves) was performed as follows for both stresses: $\mathrm{C} 1=0 \mathrm{~h}$ (sampling 1) $=$ plants unaffected by cold or salt stress; $\mathrm{C} 2=6 \mathrm{~h}$ of stress; $\mathrm{C} 3=24 \mathrm{~h}$ of stress; $\mathrm{C} 4=48 \mathrm{~h}$ of stress, and C5 $=72 \mathrm{~h}$ of stress. The experimental design was completely randomized (DIC) in a factorial $2 \times 5$ $(2 \times 5$ genotypes to stress exposure periods), with three replications per treatment. The experimental units consisted of a bulk of ten plants. Statistical analyses of the stresses were performed separately.

\section{Quantification of free proline content}

To determine the proline content, the method described by Bates et al. (1973) has been used, with some modifications. Approximately $0.5 \mathrm{~g}$ of leaf tissue were blended with $2 \mathrm{~mL}$ of aqueous solution of sulfosalicylic acid 3\% (w/v) and then centrifuged at $4000 \mathrm{~g}$ for $20 \mathrm{~min}$. The test tubes were 
filled with $1 \mathrm{~mL}$ of the supernatant, $2 \mathrm{~mL}$ of glacial acetic acid, $2 \mathrm{~mL}$ of ninhydrin acid, and $2 \mathrm{~mL}$ of distilled water, and maintained in a water bath at $100{ }^{\circ} \mathrm{C}$ for $60 \mathrm{~min}$. After this period, the tubes were cooled in an ice bath and $4 \mathrm{~mL}$ of toluene added. The samples were shaken vigorously and allowed to reach room temperature and then read in a spectrophotometer at $520 \mathrm{~nm}$. The absorbance values obtained were compared with the standard proline curve and the results expressed in $\mu \mathrm{mol}$ proline $\mathrm{g}^{-1} \mathrm{FW}$ (fresh weight). The data were subjected to analysis of variance (ANOVA) and Tukey's test (5\%), using the statistical program SAS 9.3 (SAS Institute, Cary, NC).

\section{RNA extraction, cDNA synthesis, and primer design}

Total RNA was extracted from $0.1 \mathrm{~g}$ of leaves using the PureLink $^{\circledR}$ Kit (Invitrogen ${ }^{\mathrm{TM}}$ ). For complete removal of DNA residues, the samples were treated with DNAse I (Invitrogen $^{\mathrm{TM}}$ ). The quality, concentration, and purity of total RNA were assessed by electrophoresis on $1 \%$ agarose gel and NanoDrop ND-1000. Each sample was reverse transcribed into cDNA using the commercial kit SuperScript First-Strand System for RT-PCR (Invitrogen ${ }^{\mathrm{TM}}$ ).

Primers were designed in the transcribed region of rice genes involved in the biosynthesis (P5CS1, P5CS2, P5CR, and $O A T)$ and proline catabolism $(P 5 C D H$ and $P D H)$ using the sequences deposited in the $R A P-D B$ database and the program PerlPrimer v. 1.1.21. To normalize RT-qPCR data internally, gene UBQ10, previously tested for the experimental conditions, was used (Moraes et al. 2015). Only primers with a dissociation curve with a single peak and an amplification efficiency near $100 \%$ were used in this study (Table 1).

\section{RT-qPCR reactions}

The total volume of the reactions was $12 \mu \mathrm{L}$, with $6.25 \mu \mathrm{L}$ of the reagent FastStart Universal SYBR Green Master $\left(\right.$ Roche $\left.^{\circledR}\right), 0.25 \mu \mathrm{L}(10 \mathrm{mM})$ of each primer (sense and antisense), $1 \mu \mathrm{L}$ cDNA (1:5 dilution, previously defined), and $4.25 \mu \mathrm{L}$ ultra pure water. The reactions were performed with a real-time BIO-Rad CFX-96 thermal cycler and the following amplification parameters: $95^{\circ} \mathrm{C}$ for $10 \mathrm{~min}, 40$ cycles at $95^{\circ} \mathrm{C}$ for $15 \mathrm{~s}$, and $60{ }^{\circ} \mathrm{C}$ for $1 \mathrm{~min}$ with insertion of melting curve from 65 to $95{ }^{\circ} \mathrm{C}$, with an increment of $5^{\circ} \mathrm{C}$ at each fluorescence measurement. Three technical repetitions were performed for each biological repetition, including samples for the control treatment as template-free controls. The relative quantification of the expression (RQ) of each gene was obtained, as described by Livack and Schmittgen (2001). The data were subjected to analysis of variance (ANOVA) and Tukey's test $(5 \%)$, using the statistical program SAS 9.3 (SAS Institute, Cary, NC).

\section{Correlation analysis}

To measure the intensity of correlation between the expression of each gene of proline metabolism and free proline content, the Pearson correlation coefficient was calculated for each genotype within each stress, and represented in heat maps. Analyses were performed using the

Table 1 Primer sequence of proline biosynthesis and catabolism used for gene expression analysis by RT-qPCR. Annealing temperature $60{ }^{\circ} \mathrm{C}$

\begin{tabular}{|c|c|c|c|}
\hline Gene & RAP-DB & Sense/antisense & Amplicon $(\mathrm{pb})$ \\
\hline P5CS1 & Os05t0455500-01 (AK101985) & $\begin{array}{l}5^{\prime} \text {-AGAGATTGTTCAAGGCATCTACAG-3' } \\
5^{\prime} \text {-AACCAAAGGCTTCTCATATCCAG-3' }\end{array}$ & 161 \\
\hline P5CS2 & Os01t0848200-01 (AK101230) & $\begin{array}{l}5^{\prime} \text {-GGTTGATTATCCAGCAGCGT-3' } \\
5^{\prime} \text {-CCCGCCATAGATAACTACCC-3' }\end{array}$ & 150 \\
\hline P5CR & Os01t0948400-01 (AK070184) & $\begin{array}{l}5^{\prime} \text {-GTTGGTCTGGTCATCGAAGATT-3' } \\
5^{\prime} \text {-CATTCTCAGTAGCCATCTCCC-3' }\end{array}$ & 104 \\
\hline $\mathrm{P} 5 \mathrm{CDH}$ & Os05t0536400-01 (AK121765) & $\begin{array}{l}5^{\prime} \text {-AGCAGAGGATGTGGACTTCA-3' } \\
5^{\prime} \text {-GCCTTTCAAATCAGCAGCC-3' }\end{array}$ & 132 \\
\hline$P D H$ & Os10t0550900-01 (AK121010) & $\begin{array}{l}5^{\prime} \text {-GGGTTCCAGGTGAGCAAG-3' } \\
5^{\prime} \text {-AAGGAGGAAGACGAGAGCA-3' }\end{array}$ & 106 \\
\hline$O A T$ & Os03t0643300-01 (AK108010) & $\begin{array}{l}5^{\prime} \text {-TGCTGTGTATCAAACCAGGA-3' } \\
5^{\prime} \text {-CTTTCAACGAGACCTTCATCTG-3' }\end{array}$ & 160 \\
\hline$U B Q 10$ & Os02t0161900-01 (AK101547) & $\begin{array}{l}5^{\prime} \text {-TGGTCAGTAATCAGCCAGTTTGG-3' } \\
5^{\prime} \text {-GCACCACAAATACTTGACGAACAG-3' }\end{array}$ & 105 \\
\hline
\end{tabular}


SAS v.9.3 software (SAS Institute Inc., Cary, NC) with the procedures proc corr and proc sgrender.

\section{Results}

\section{Free proline content}

According to the results of analysis of variance, there was a significant effect of interaction between the factors $(2$ genotypes $\times 5$ stress exposure periods) for the free proline content under both cold and salt stress. The proline content increased after $6 \mathrm{~h}$ of stress and reached the highest level after $72 \mathrm{~h}$ under both genotypes, in response to the salt treatment. For the (sensitive) genotype BRS Pampa, values ranged from 1.62 to $3.53 \mu \mathrm{mol}$ proline $\mathrm{g}^{-1} \mathrm{FW}$, with a 2.2 fold increase compared to the control, while in genotype BRS Bojuru (tolerant), the increase was 3.2-fold after $72 \mathrm{~h}$ of stress, compared to the control. In a comparison of the genotypes, there was a statistical difference between the stress periods of 6 and $48 \mathrm{~h}$.

Under cold stress, there was a 1.3- and 2.2-fold increase in proline content in a period of $72 \mathrm{~h}$ over the control for BRS Pampa and BRS Bojuru, respectively, although this increase was statistically not significant, compared to the control plants. For BRS Pampa, the period of 6 and $48 \mathrm{~h}$ differed from the 72-h stress period, while for BRS Bojuru, the 24-h stress period differed statistically from the control treatment and from $48 \mathrm{~h}$ (Fig. 1).

\section{Expression of proline metabolism genes}

The analysis of variance for relative expression of the genes showed that the values were significantly different $(p \leq 0.05)$ to the times of the exposure in $\mathrm{NaCl}$ and low temperature, except for PC5S2 (BRS Bojuru) and PDH (BRS Pampa) under salinity (Tables 2, 3).

The increase in proline content observed in the two genotypes under salinity and low temperature probably occurred due to the increase in the expression of genes P5CS1 and P5CR involved in the biosynthesis of this amino acid, accompanied by minor changes in the expression of $P 5 C D H$ and $P D H$ involved in mitochondrial proline catabolism (Figs. 2, 3).

For gene P5CS1, with preferential protein accumulation in the chloroplast when under stress, a gradual increase in mRNA levels was observed during the salt exposure period, peaking at 8.78 and 11.28 in the tolerant and sensitive genotypes, respectively, after $72 \mathrm{~h}$ of stress (Fig. 2a, c). In the cold treatment, the expression of gene P5CSI increased in all stress periods. However, the highest values of relative quantification (RQ) were 4.75 (tolerant genotype) and 3.49 (sensitive genotype) times higher than of the control after

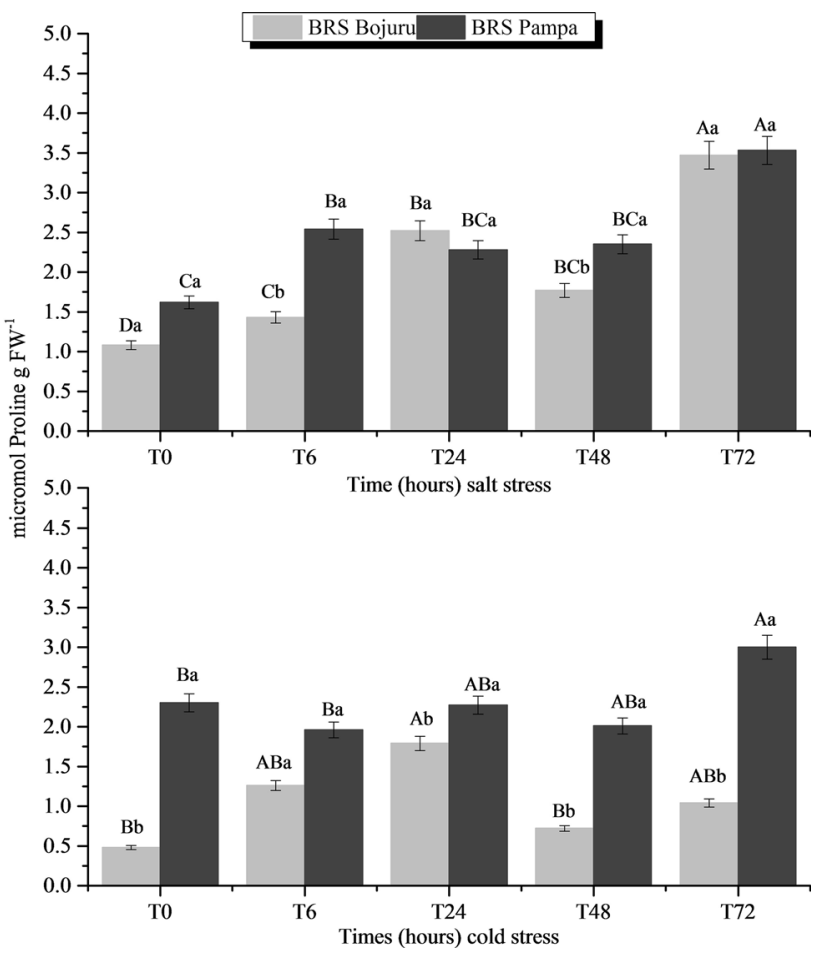

Fig. 1 Free proline content in two rice genotypes under salt stress $(150 \mathrm{mM} \mathrm{NaCl})$ and low temperature $\left(13^{\circ} \mathrm{C}\right)$. The values are represented by the mean $\pm \mathrm{SD}$ for each treatment $(n=3)$. Means followed by the same capital letters are not statistically different in the stress period for each genotype and equal lowercase letters do not differ among the genotypes within each stress period

72 h (Fig. 3a, c). The gene P5CR, which reduces P5C to proline, increased expression with 4.22 and 2.93 times higher RQ values in tolerant and sensitive genotypes under salinity, respectively, and 2.58 and 2.82 under cold in the last sampling (Figs. 2a, c, 3a, c). However, under cold in sensitive genotype, the amount of P5CR transcripts was lower than of the control after 6,24 , and $48 \mathrm{~h}$, increasing until $72 \mathrm{~h}$ of stress $(\mathrm{RQ}=2.82)$ (Fig. $3 \mathrm{c}$ ).

The genes P5C dehydrogenase $(P 5 C D H)$ and proline dehydrogenase $(P D H)$ involved in proline catabolism were less responsive under stress application than the synthesis genes, with $P 5 C D H$ and $P D H$ values between 1.12-1.85 and $0.92-1.98$ for BRS Bojuru and 1.20-1.88 and 0.73-1.10 for BRS Pampa (Fig. 2b, d). During cold stress, the $P 5 C D H$ expression in BRS Bojuru varied between 1.1 and 1.98 , similar to salt stress, while $P D H$ was below the control at all sampling times. In BRS Pampa, the expression was between 0.91 and $1.86(P 5 C D H)$ and 1.12 and $1.31(P D H)$ (Fig. 3b, d).

In addition, proline biosynthesis occurs by the catalytic activity of the isoform gene P5CS2 and via ornithine by the enzyme activity of ornithine delta aminotransferase (OAT). The gene expression of P5CS2, which accumulates protein preferentially in the cytosol, was higher in the salt-sensitive 
Table 2 Relative quantification (RQ) of gene expression of proline biosynthesis (P5CS1, P5CS2, P5CR, and AOT) and catabolism ( $P 5 C D H$ and $P D H)$ in rice genotypes under salinity $(150 \mathrm{mM} \mathrm{NaCl})$
Table 3 Relative quantification (RQ) of gene expression of proline biosynthesis (P5CS1, $P 5 C S 2, P 5 C R$, and $A O T)$ and catabolisms $(P 5 C D H$ and $P D H)$ in rice genotypes at low temperature $\left(13^{\circ} \mathrm{C}\right)$

\begin{tabular}{|c|c|c|c|c|c|c|}
\hline \multirow[t]{2}{*}{ Genes } & \multirow[t]{2}{*}{ Genotypes } & \multicolumn{5}{|c|}{ Times (h) salt stress } \\
\hline & & T0 & T6 & $\mathrm{T} 24$ & $\mathrm{~T} 48$ & $\mathrm{~T} 72$ \\
\hline \multirow[t]{2}{*}{ P5CS1 } & BRS Bojuru & $1.00^{\mathrm{C}}$ & $1.64 \pm 0.20^{\mathrm{C}}$ & $1.90 \pm 0.38^{\mathrm{C}}$ & $3.54 \pm 0.3^{\mathrm{B}}$ & $8.78 \pm 0.31^{\mathrm{A}}$ \\
\hline & BRS Pampa & $1.00^{\mathrm{D}}$ & $1.45 \pm 0.25^{\mathrm{D}}$ & $6.95 \pm 0.37^{\mathrm{C}}$ & $9.86 \pm 0.39^{\mathrm{B}}$ & $11.28 \pm 0.28^{\mathrm{A}}$ \\
\hline \multirow[t]{2}{*}{$P 5 C S 2$} & BRS Bojuru & $1.00^{\mathrm{A}}$ & $0.99 \pm 0.26^{\mathrm{A}}$ & $1.13 \pm 0.37^{\mathrm{A}}$ & $1.12 \pm 0.40^{\mathrm{A}}$ & $1.61 \pm 0.29^{\mathrm{A}}$ \\
\hline & BRS Pampa & $1.00^{\mathrm{C}}$ & $1.95 \pm 0.30^{\mathrm{BC}}$ & $4.14 \pm 0.48^{\mathrm{AB}}$ & $4.33 \pm 0.37^{\mathrm{A}}$ & $5.95 \pm 0.43^{\mathrm{A}}$ \\
\hline \multirow[t]{2}{*}{$P 5 C R$} & BRS Bojuru & $1.00^{\mathrm{D}}$ & $2.04 \pm 0.31^{\mathrm{B}}$ & $2.20 \pm 0.49^{\mathrm{B}}$ & $1.66 \pm 0.41^{\mathrm{C}}$ & $4.22 \pm 0.37^{\mathrm{A}}$ \\
\hline & BRS Pampa & $1.00^{\mathrm{B}}$ & $2.15 \pm 0.44^{\mathrm{A}}$ & $2.01 \pm 0.52^{\mathrm{AB}}$ & $2.05 \pm 0.37^{\mathrm{AB}}$ & $2.93 \pm 0.40^{\mathrm{A}}$ \\
\hline \multirow[t]{2}{*}{$\mathrm{P} 5 \mathrm{CDH}$} & BRS Bojuru & $1.00^{\mathrm{B}}$ & $1.12 \pm 0.52^{\mathrm{B}}$ & $1.62 \pm 0.40^{\mathrm{AB}}$ & $1.35 \pm 0.50^{\mathrm{AB}}$ & $1.85 \pm 0.41^{\mathrm{A}}$ \\
\hline & BRS Pampa & $1.00^{\mathrm{B}}$ & $1.88 \pm 0.30^{\mathrm{A}}$ & $1.60 \pm 0.50^{\mathrm{AB}}$ & $1.51 \pm 0.35^{\mathrm{AB}}$ & $1.20 \pm 0.46^{\mathrm{AB}}$ \\
\hline \multirow[t]{2}{*}{$P D H$} & BRS Bojuru & $1.00^{\mathrm{BC}}$ & $0.92 \pm 0.32^{\mathrm{C}}$ & $1.02 \pm 0.41^{\mathrm{BC}}$ & $1.98 \pm 0.36^{\mathrm{A}}$ & $1.70 \pm 0.24^{\mathrm{AB}}$ \\
\hline & BRS Pampa & $1.00^{\mathrm{A}}$ & $1.10 \pm 0.21^{\mathrm{A}}$ & $0.81 \pm 0.34^{\mathrm{A}}$ & $0.82 \pm 0.28^{\mathrm{A}}$ & $0.73 \pm 0.32^{\mathrm{A}}$ \\
\hline \multirow[t]{2}{*}{$A O T$} & BRS Bojuru & $1.00^{\mathrm{A}}$ & $1.35 \pm 0.48^{\mathrm{A}}$ & $1.84 \pm 0.27^{\mathrm{A}}$ & $3.24 \pm 0.37^{\mathrm{B}}$ & $3.58 \pm 0.24^{\mathrm{B}}$ \\
\hline & BRS Pampa & $1.00^{\mathrm{B}}$ & $1.47 \pm 0.32^{\mathrm{A}}$ & $1.40 \pm 0.44^{\mathrm{A}}$ & $1.69 \pm 0.36^{\mathrm{A}}$ & $1.36 \pm 0.37^{\mathrm{AB}}$ \\
\hline
\end{tabular}

Mean $\pm \mathrm{SD}, n=3$. Significant differences ( $p \leq 0.05$, Tukey's test) between times (h) salt stress for each gene and genotype are indicated by different letters

\begin{tabular}{|c|c|c|c|c|c|c|}
\hline \multirow[t]{2}{*}{ Genes } & \multirow[t]{2}{*}{ Genotypes } & \multicolumn{5}{|c|}{ Times (h) cold stress } \\
\hline & & T0 & T6 & $\mathrm{T} 24$ & $\mathrm{~T} 48$ & T72 \\
\hline \multirow[t]{2}{*}{ P5CS1 } & BRS Bojuru & $1.00^{\mathrm{C}}$ & $1.33 \pm 0.28^{\mathrm{C}}$ & $2.18 \pm 0.35^{\mathrm{B}}$ & $1.79 \pm 0.41^{\mathrm{C}}$ & $4.75 \pm 0.27^{\mathrm{A}}$ \\
\hline & BRS Pampa & $1.00^{\mathrm{B}}$ & $1.75 \pm 0.45^{\mathrm{B}}$ & $2.91 \pm 0.41^{\mathrm{A}}$ & $1.76 \pm 0.45^{\mathrm{B}}$ & $3.49 \pm 0.30^{\mathrm{A}}$ \\
\hline \multirow[t]{2}{*}{ P5CS2 } & BRS Bojuru & $1.00^{\mathrm{A}}$ & $0.76 \pm 0.26^{\mathrm{AB}}$ & $0.49 \pm 0.27^{\mathrm{B}}$ & $0.46 \pm 0.34^{\mathrm{B}}$ & $0.57 \pm 0.29^{\mathrm{B}}$ \\
\hline & BRS Pampa & $1.00^{\mathrm{A}}$ & $0.49 \pm 0.28^{\mathrm{B}}$ & $0.52 \pm 0.32^{\mathrm{B}}$ & $0.69 \pm 0.24^{\mathrm{AB}}$ & $0.83 \pm 0.38^{\mathrm{AB}}$ \\
\hline \multirow[t]{2}{*}{$P 5 C R$} & BRS Bojuru & $1.00^{\mathrm{B}}$ & $2.34 \pm 0.31^{\mathrm{A}}$ & $2.36 \pm 0.39^{\mathrm{A}}$ & $2.37 \pm 0.43^{\mathrm{A}}$ & $2.58 \pm 0.40^{\mathrm{A}}$ \\
\hline & BRS Pampa & $1.00^{\mathrm{B}}$ & $0.53 \pm 0.22^{\mathrm{C}}$ & $0.81 \pm 0.33^{\mathrm{BC}}$ & $0.74 \pm 0.27^{\mathrm{BC}}$ & $2.82 \pm 0.38^{\mathrm{A}}$ \\
\hline \multirow[t]{2}{*}{$\mathrm{P} 5 \mathrm{CDH}$} & BRS Bojuru & $1.00^{\mathrm{B}}$ & $1.98 \pm 0.52^{\mathrm{A}}$ & $1.01 \pm 0.38^{\mathrm{B}}$ & $1.29 \pm 0.45^{\mathrm{AB}}$ & $1.86 \pm 0.41^{\mathrm{A}}$ \\
\hline & BRS Pampa & $1.00^{\mathrm{AB}}$ & $0.90 \pm 0.48^{\mathrm{B}}$ & $1.37 \pm 0.29^{\mathrm{AB}}$ & $1.86 \pm 0.47^{\mathrm{A}}$ & $1.20 \pm 0.33^{\mathrm{B}}$ \\
\hline \multirow[t]{2}{*}{$P D H$} & BRS Bojuru & $1.00^{\mathrm{A}}$ & $0.29 \pm 0.32^{\mathrm{C}}$ & $0.87 \pm 0.21^{\mathrm{AB}}$ & $0.53 \pm 0.36^{\mathrm{BC}}$ & $0.80 \pm 0.24^{\mathrm{AB}}$ \\
\hline & BRS Pampa & $1.00^{\mathrm{B}}$ & $1.31 \pm 0.39^{\mathrm{A}}$ & $1.17 \pm 0.28^{\mathrm{AB}}$ & $1.12 \pm 0.42^{\mathrm{AB}}$ & $1.26 \pm 0.31^{\mathrm{A}}$ \\
\hline \multirow[t]{2}{*}{$A O T$} & BRS Bojuru & $1.00^{\mathrm{C}}$ & $0.80 \pm 0.28^{\mathrm{C}}$ & $1.86 \pm 0.40^{\mathrm{B}}$ & $2.73 \pm 0.37^{\mathrm{A}}$ & $2.46 \pm 0.24^{\mathrm{A}}$ \\
\hline & BRS Pampa & $1.00^{\mathrm{AB}}$ & $0.69 \pm 0.42^{\mathrm{C}}$ & $0.92 \pm 0.44^{\mathrm{B}}$ & $1.24 \pm 0.38^{\mathrm{A}}$ & $0.90 \pm 0.35^{\mathrm{B}}$ \\
\hline
\end{tabular}

Mean $\pm \mathrm{SD}, n=3$. Significant differences ( $p \leq 0.05$, Tukey's test) between times (h) salt stress for each gene and genotype are indicated by different letters genotype, reaching the highest mRNA level after $72 \mathrm{~h}$ of stress $(\mathrm{RQ}=5.95)$. On the other hand, the $O A T$ gene was also more responsive in the tolerant genotype after $72 \mathrm{~h}$ $(\mathrm{RQ}=3.58)($ Fig. $4 \mathrm{a}, \mathrm{b})$. In cold treatment, the P5CS2 expression values were lower than the control after all stress periods in both genotypes. However, the same was not true for $O A T$, which was more responsive in tolerant genotype after $48 \mathrm{~h}$ of stress $(\mathrm{RQ}=2.73)($ Fig. $4 \mathrm{c}, \mathrm{d})$.

\section{Correlation}

Under salt stress, the amplitude of variation of correlations was 0.42-0.99 between the proline content and gene expression, for BRS Bojuru and -0.54 to 0.97 for BRS
Pampa (Fig. 5a, b). Thus, for the tolerant genotype, all correlations between proline content and gene expression were significant and highly correlated with $P 5 C D H$, $P 5 C S 2$, and P5CR and low correlation with $P D H$. Considering the correlation coefficients between the genes of proline metabolism, P5CS2 was highly correlated with P5CS1 (0.98) and P5CR (0.93), respectively. Similar values were found for the pairs P5CSI/P5CR (0.91) and OAT/ $P D H$ (0.92), whereas the lowest correlation was observed for the pair PDH/P5CR (0.37) (Fig. 5a).

Contrasting responses were observed in sensitive genotype, for which he was found negative correlation value between proline content and $P D H$ gene $(-0.54)$, while the P5CS2 gene showed the most positive correlation with 


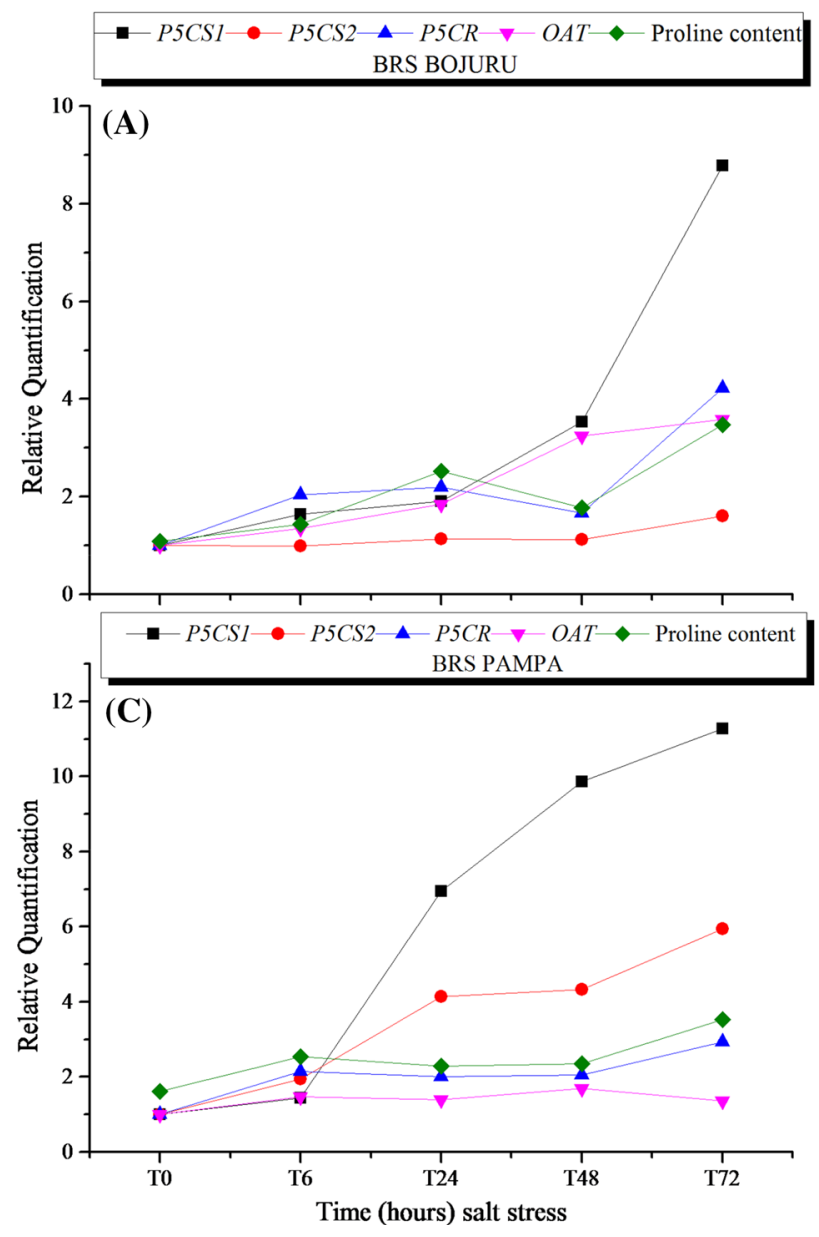

Fig. 2 Relative quantification (RQ) of gene expression of proline biosynthesis (P5CS1, P5CS2, P5CR, and AOT) and catabolism $(P 5 C D H$ and $P D H)$ and quantification of free proline content in rice

proline content (0.97). Among the genes involved in proline biosynthesis, had P5CS1 correlation with P5CS2 and 0.73-0.10 with P5CR. For the $P D H$ gene, except for $P D H /$ $P 5 C R$, negative correlation estimates were observed between $P D H$ and all other genes, with values ranging from -0.28 (PDH/OAT) and -0.94 (PDH/P5CS1), indicating contrasting response expression in each gene pair. By analyzing the correlations between the other combinations, it was found that proline content/P5CR, P5CS1/ $P 5 C R$, and $P 5 C D H / P 5 C R$ was no correlation. Moreover, the correlation between estimated proline content/P5CS2 P5CSI and/P5CDH highly frequent (0.97) (Fig. 5b).

In the cold treatment, the correlations between the tested genes and the proline content were low for the tolerant genotype. The highest value was observed for $P 5 C R /$ proline content (0.60), while gene P5CS2 was least correlated with the proline content $(-0.51)$. Analyzing the gene combinations, high negative correlations were observed with gene P5CS2, namely: P5CS2/P5CR $(-0.85), \quad P 5 C S 2 / O A T \quad(-0.81)$, and P5CS2/P5CS1

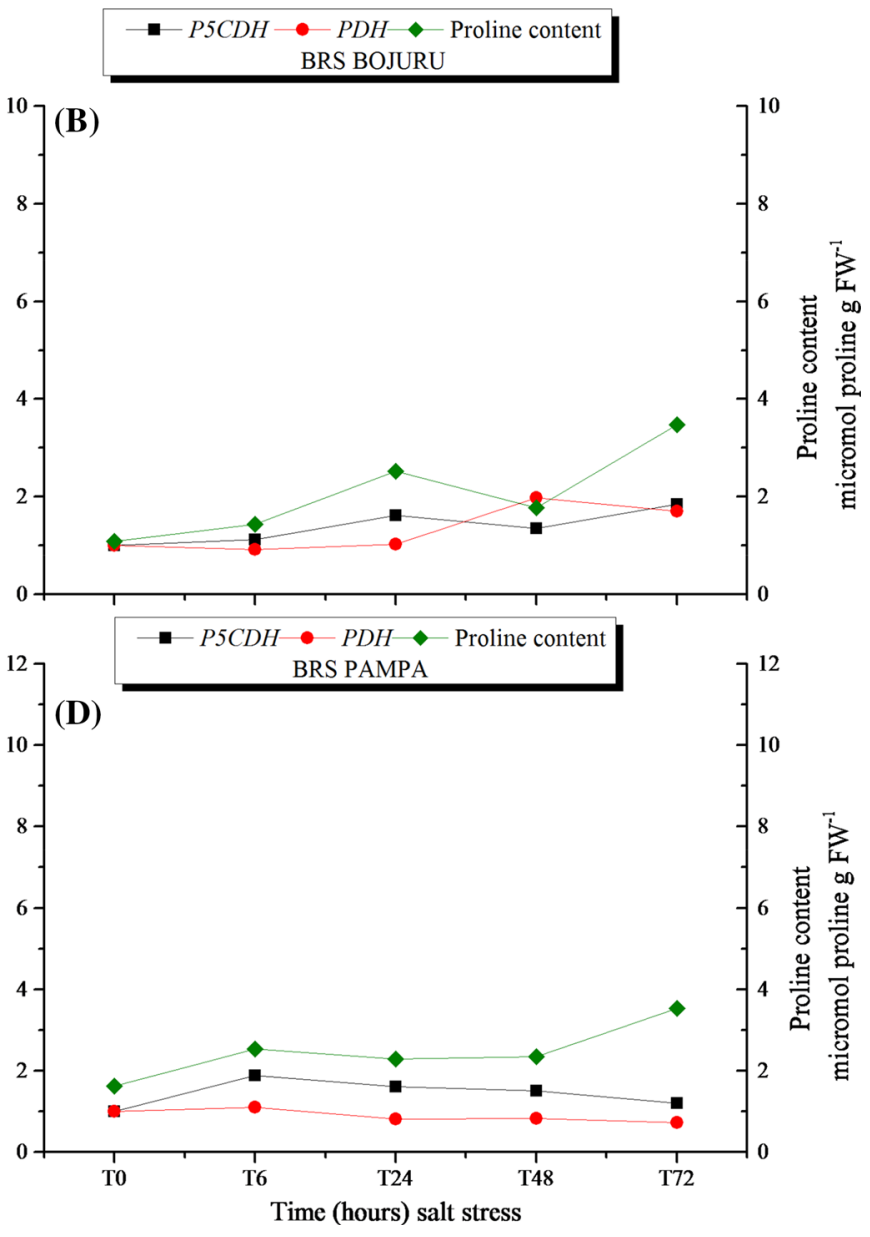

genotypes BRS Bojuru (a, b) and BRS Pampa (c, d) under salinity $(150 \mathrm{mM} \mathrm{NaCl})$. The points are represented by the mean for each treatment $(n=3)$

(-0.48). No correlation was found for P5CS2/P5CDH $(-0.07), \quad O A T /$ proline content $(-0.01), O A T / P 5 C D H$ (-0.05), OAT/PDH (0.09), and $P 5 C D H /$ proline content $(0.10)$. On the other hand, the other combinations correlated positively, but with lower values than those found in the $\mathrm{NaCl}$ treatment (Fig. 6a).

For the sensitive genotype, the proline content was positively correlated with the genes P5CS1 (0.70) and P5CR (0.97), whereas with OAT, the value was negative $(-0.48)$. Genes involved in proline biosynthesis were not closely correlated with each other, since for P5CS1/P5CS2, the value was -0.26 , for P5CS1/P5CR 0.68 and for P5CS2/P5CR 0.48. Most negative correlations were observed in combinations with the $O A T$ gene and no correlation in combinations with $\mathrm{P} 5 \mathrm{CDH}$ (Fig. 6b). The responses of the two genotypes were contrasting, especially with regard to the proline content and expression of proline biosynthesis genes (P5CS1, P5CS2, and P5CR), for which the correlations of combination had different trends (Fig. 6a, b). 

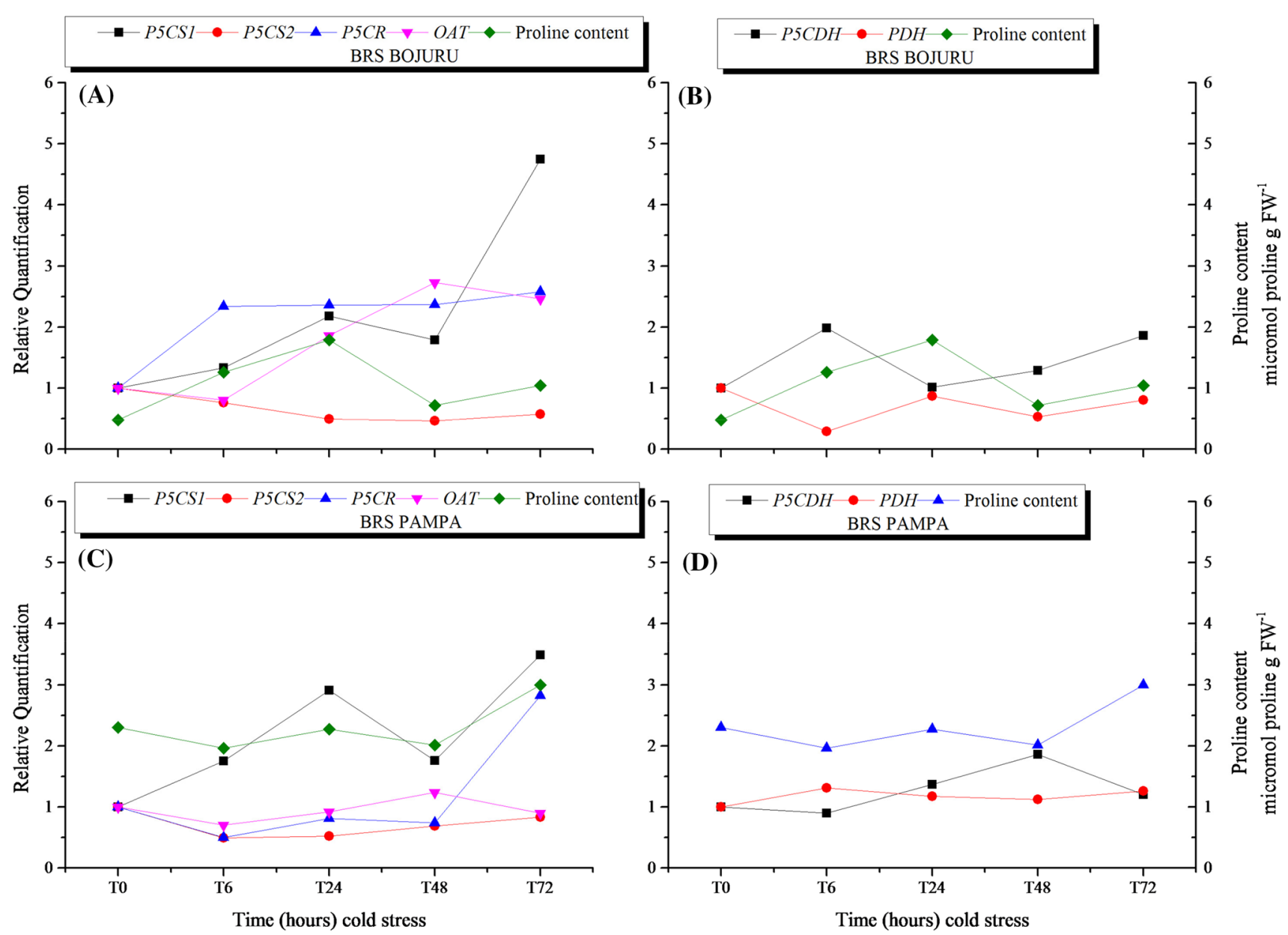

Fig. 3 Relative quantification (RQ) of gene expression of proline biosynthesis (P5CS1, P5CS2, P5CR, and OAT) and catabolism $(P 5 C D H$ and $P D H)$ and quantification of free proline content in rice

\section{Discussion}

The osmotic adjustment is one of the most effective physiological mechanisms for the maintenance of cell turgor under conditions of low water potential in the soil caused, among others, by drought, salinity, and low atmospheric temperature (Marijuan and Bosch 2013). This mechanism is established by the accumulation of compatible solutes (proline, glycine betaine, trehalose, sucrose, polyamines, mannitol, and pinitol) that contribute to the maintenance of the intracellular water balance and preservation of the integrity of proteins, enzymes, and cell membranes (Ashraf et al. 2011). In this study, proline metabolism in rice plants was evaluated based on the expression pattern of genes involved in biosynthesis and catabolism of amino acid. It was found that the amount of transcripts is directly related to the proline content produced under salinity and cold stress.

An increase in proline content was observed in both treatments and genotypes, but was greater in BRS Bojuru

genotypes BRS Bojuru (a, b) and BRS Pampa (c, d) at low temperature $\left(13^{\circ} \mathrm{C}\right)$. The points are represented by the mean for each treatment $(n=3)$

(tolerant) under both experimental conditions. Under salt stress, changes in proline content already occurred at the beginning of stress. Peaks were reached under severe stress $(72 \mathrm{~h})$ in both genotypes, and the increase was greater in the tolerant genotype than the control. Under cold stress, it was also noted that the tolerant genotype had double the increase of sensitive genotype compared to control plants exposed to $72 \mathrm{~h}$ of cold (Fig. 1). Similar results were obtained by Hien et al. (2003), who observed a relative increase in proline content in saline-tolerant rice cultivars $48 \mathrm{~h}$ after stress application, whereas no increases were observed for the sensitive cultivar, even after $72 \mathrm{~h}$ of treatment with $200 \mathrm{mM} \mathrm{NaCl}$. These different responses of genotypes may be associated with signaling cascades that regulate the proline metabolism, which are controlled by multiple cellular mechanisms and which should be further investigated (Bhaskara et al. 2015). Among the factors involved, abscisic acid (ABA) and calcium play a positive role in gene signaling and expression related to proline biosynthesis. On the other hand, phospholipase D (PLD) 

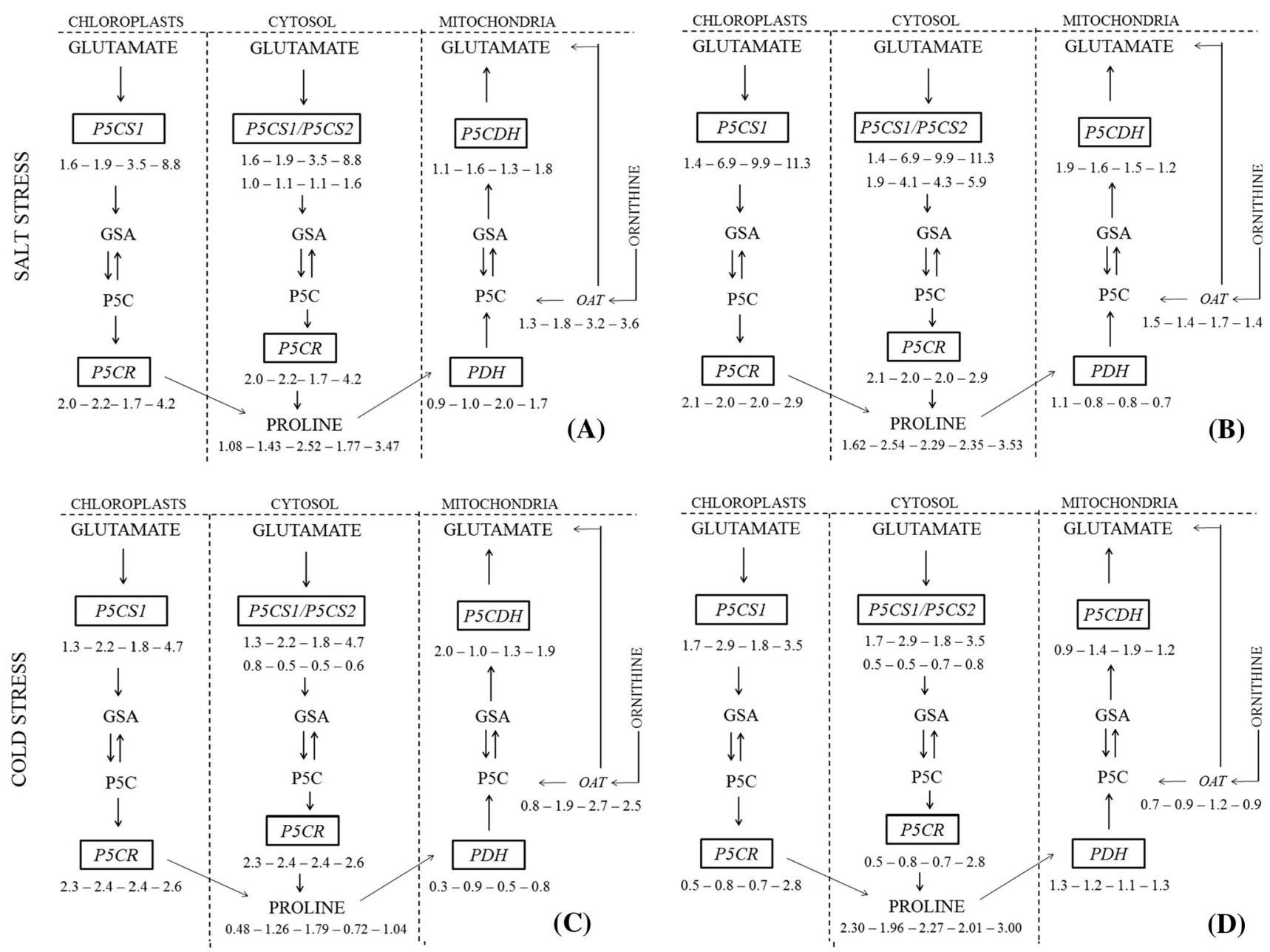

Fig. 4 Diagram of proline metabolism with the respective expression values in relation to the genes involved (starting from T6 on the left) and the proline content (starting from T0 on the left) in rice plants of genotypes BRS Bojuru (a, c) and BRS Pampa (b, d), under salt and cold stress

regulates the biosynthesis of amino acid negatively (Thiery et al. 2004). Thus, the factors that regulate this signaling are possibly first positively activated in plants tolerant to osmotic stress caused also by salinity and cold.

Two pathways were described for proline biosynthesis, the glutamate pathway and the ornithine pathway. From glutamate, proline is synthesized by pyrroline-5-carboxylate (P5C) by reactions catalyzed by the enzymes P5C synthase (P5CS) and pyrroline-5-carboxylate reductase P5CR, whose genes have been identified and isolated in many plant species (Satoh et al. 2002; Winter et al. 2015).

During the $\mathrm{NaCl}$ treatment in this study, the transcription of both isoforms of P5CS in genotype BRS Pampa (sensitive) was increased compared to the control. In genotype BRS Bojuru (tolerant), increases in the expression for P5CS1 were also observed during stress, while the mRNA level of isoform P5CS2 was similar between the sampling times. Although the transcript levels were lower for the tolerant genotype, some correlations were higher, and for proline content/P5CS1, the correlation was 0.85 and 0.98 for P5CS1/P5CS2 (Fig. 5a). This behavior can be explained by the fact that the transcriptional level not always directly related to the enzymatic activity, since several regulatory systems are involved in the final protein availability and activity. In one of the first studies, Anderson and Seilhamer (1997) compared the levels of mRNA with the corresponding proteins, in which the correlation was only 0.43 .

Previous studies have also demonstrated the correlation between the induction of P5CS gene and the accumulation of proline in sorghum under abiotic stresses and MeJA treatment (Su et al. 2011). For ryegrass, Li et al. (2014) found a high cause-effect relationship between the increase in transcripts of both isoforms of P5CS and the proline content, which was upregulated after stress. In rice plants, Hur et al. (2004) found that the expression of gene P5CSI was constant, while P5CS2 was induced by mannitol and $\mathrm{NaCl}$.

Under low temperatures, the levels of P5CS1 expression increased in both genotypes, but less than under salinity. 


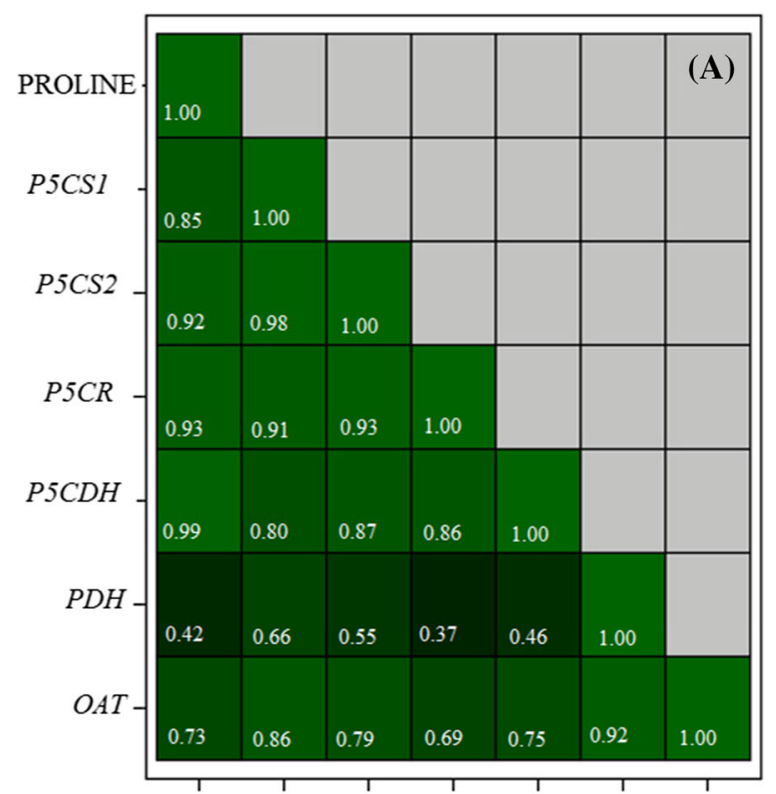

PROLINE P5CSI P5CS2 P5CR P5CDH PDH OAT

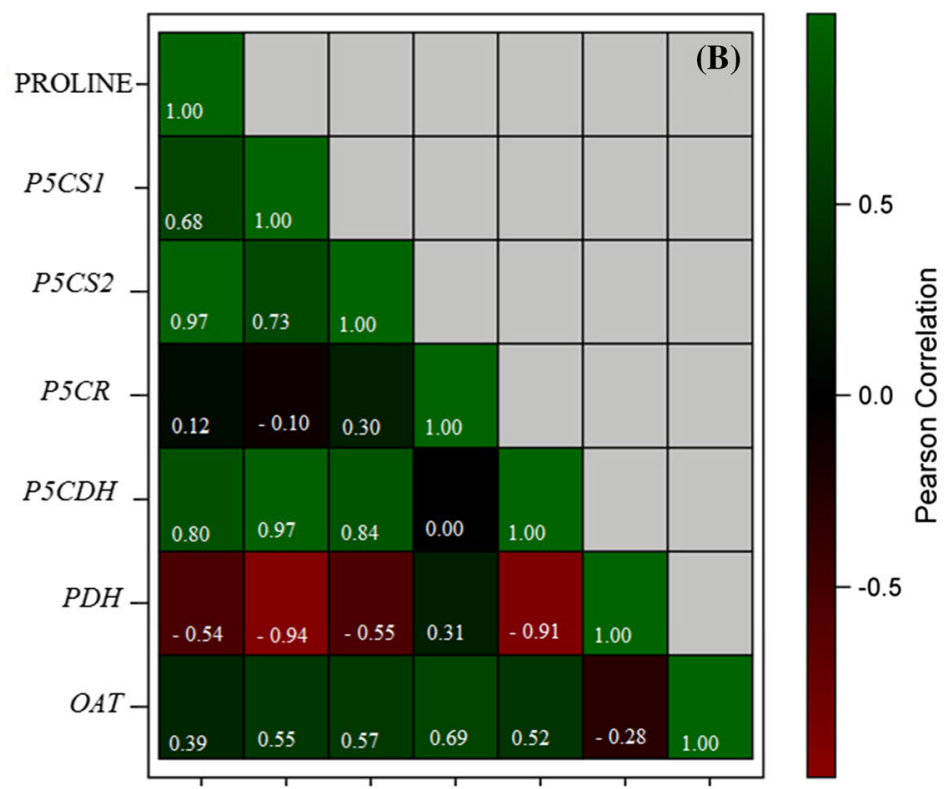

PROLINE P5CSI P5CS2 P5CR P5CDH PDH OAT

Fig. 5 Pearson correlation between the free proline content and expression of proline metabolism genes in rice genotypes BRS Bojuru (a) and BRS Pampa (b) under salt stress $(150 \mathrm{mM} \mathrm{NaCl})$

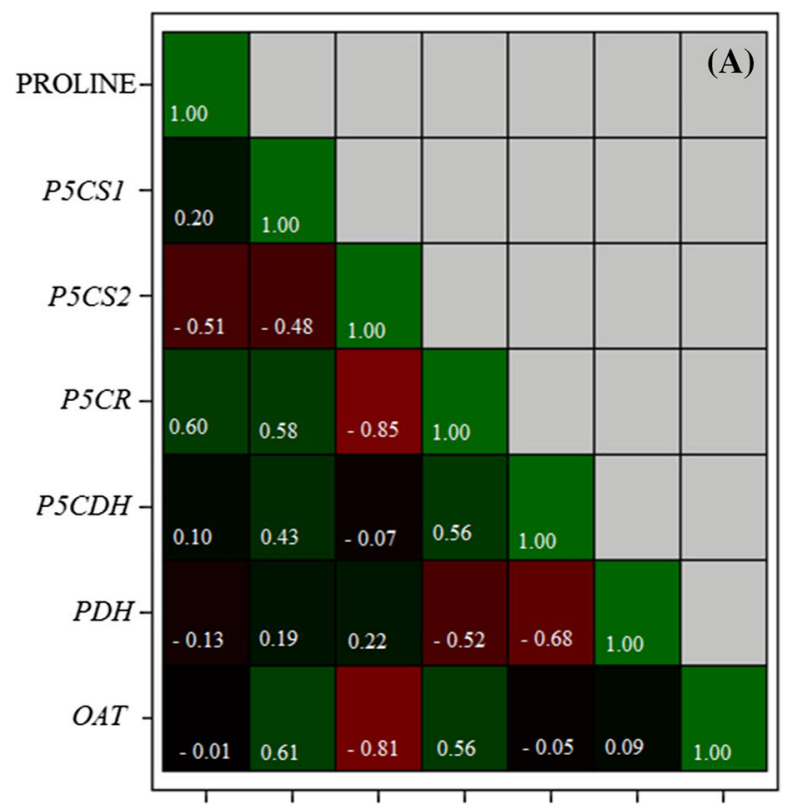

PROLINE P5CS1 P5CS2 P5CR P5CDH PDH OAT

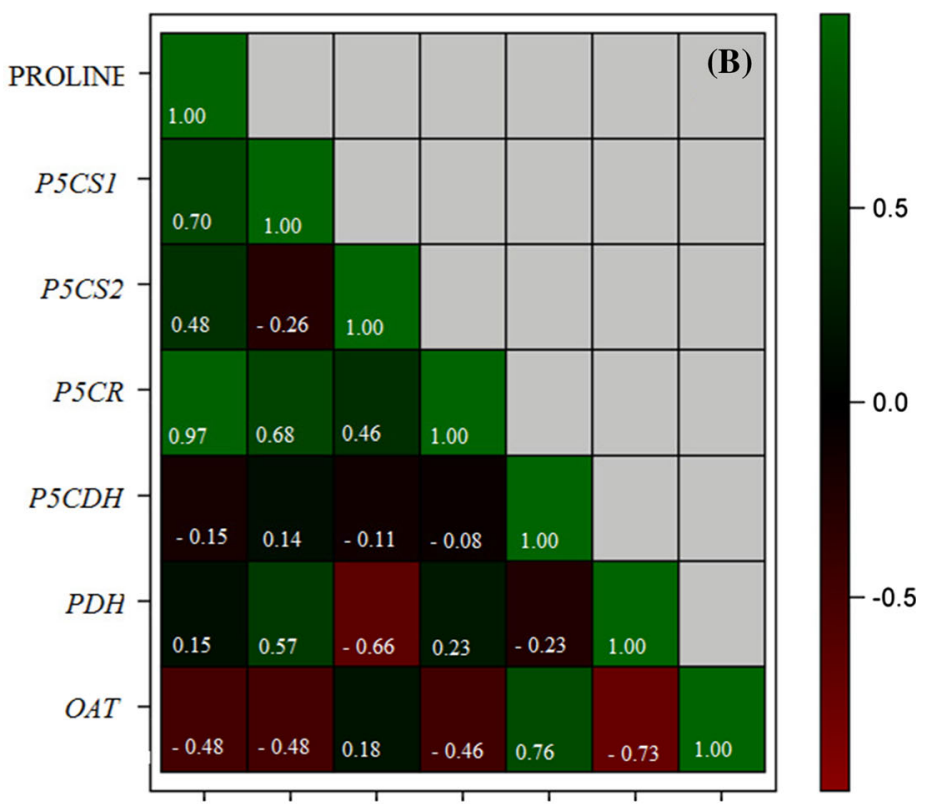

PROLINE P5CS1 P5CS2 P5CR P5CDH PDH OAT

Fig. 6 Pearson correlation between the free proline content and expression of proline metabolism genes in rice genotypes BRS Bojuru (a) and BRS Pampa (b) under cold stress $\left(13{ }^{\circ} \mathrm{C}\right)$

Conversely, P5CS2 was negatively regulated by cold, with measurement values below the control and correlation of 0.50 and 0.48 between proline content/P5CS2 in the tolerant and sensitive genotypes, respectively (Figs. 4c, d, 6). According to Kavikishor et al. (2015), it is not yet clear how these genes interact with other genes through networks of cellular components. Thus, the availability of maps of these networks could help understand the regulation of proline metabolism and justify the contrasting responses to the different tested conditions (salinity and cold).

The enzyme pyrroline-5-carboxylate reductase (P5CR), encoded by gene $P 5 C R$, is a precursor of proline biosynthesis in plants. In this study, contrasting responses were observed again, between stresses as well as between 
cultivars. In plants of the tolerant genotype (BRS Bojuru), the $P 5 C R$ expression was increased and the correlation between proline content/P5CR under salinity was high. As mentioned above, proline biosynthesis can occur both in the cytosol and the chloroplast. Under stress, the preferred pathway is the chloroplast pathway, by the genes P5CSI and P5CR. The correlations of this study showed that proline biosynthesis may have occurred at both cell locations in the salt-stressed tolerant genotype, since high correlations between proline content/P5CS1 and proline content/P5CS2 were observed, aside from significant relations between P5CS1/P5CR and P5CS2/P5CR (Figs. 4a, 5a).

On the other hand, for the sensitive genotype, although increases in the P5CR expression were observed, the correlation of this gene with proline content was only 00.12 . Analyzing the correlations, it is believed that the preferred pathway of proline biosynthesis in the sensitive genotype occurred by the cytosol, since higher relations were observed between proline content/P5CS2 (0.97) and P5CS2/P5CR (0.30) versus 0.68 between proline content/ P5CS1 and -0.10 between P5CS1/P5CR (Figs. 4b, 5b). Similar results to the sensitive genotype were observed in Arabidopsis thaliana and rice under osmotic stress, where only the P5CS expression was correlated with proline concentration, and the $P 5 C R$ expression was not correlated (Sripinyowanich et al. 2013).

Under cold stress, the response of P5CR gene had the same tendency as the proline content in sensitive plants, with significantly higher values than the control, explaining the high correlation between proline content/P5CR for genotype BRS Pampa. For BRS Bojuru, this correlation was lower, which can be explained by the significant changes in P5CR expression levels, differing from proline content, which changed during the period of cold stress. Unlike for salt stress, it is believed that the preferred proline biosynthesis pathway under cold stress is by the chloroplast for both genotypes, since higher correlations were observed between proline content/P5CS1, P5CSI/ P5CR for BRS Pampa and proline content/P5CS1, P5CS1/ $P 5 C R$ for BRS Bojuru (Figs. 6a, b). It is well-documented that the regulation of $P 5 C S$ and $P 5 C R$ depends on the cofactor NADH or NADPH (Giberti et al. 2014). Thus, this adjustment possibly has a stronger effect on the chloroplast of both genotypes under cold stress.

Similar to the important role of proline biosynthesis for stressed plants, a rapid proline degradation is a way of minimizing stress effects, for providing reducing agents that support the mitochondrial oxidative phosphorylation and generate ATP for plant recovery from stress and repair of accumulated damage. Proline catabolism occurs in mitochondria by the sequential action of proline dehydrogenase $(\mathrm{PDH})$ and $\mathrm{P} 5 \mathrm{C}$ dehydrogenase $(\mathrm{P} 5 \mathrm{CDH})$, which converts P5C to glutamate (Szabados and Savouré 2010). For the tolerant genotype, the data of the experiment with salt stress showed a correlation between proline content accumulation and $P D H$ gene expression of 0.42 , justified by the opposite response behavior after all stress periods. For the sensitive genotype, there was a negative correlation between these variables (Figs. 2, 5). In the cold treatment, the response was opposite to that to salinity; for the tolerant genotype, the correlation proline content/PDH was negative and for the sensitive genotype, the correlation was insignificant (Fig. 6a, b).

According to Satoh et al. (2002), the gene expression of $P D H$ is repressed under dehydration, but is induced when plants are rehydrated after $10 \mathrm{~h}$ of stress. Therefore, deepening the understanding of $P D H$ expression can be useful to shed light on the molecular process of plant recovery from osmotic stress. These same authors determined that the ACTCAT cis-element, present in the promoter region, is involved in the regulation of $P D H$ gene expression under hypoosmolarity.

Pyrroline-5-carboxylate (P5C) is an intermediate product of both proline biosynthesis and degradation. It is synthesized in the mitochondria during catabolism by enzyme PDH and converted to glutamate by 1-pyrroline dehydrogenase-5-carboxylate (P5CDH) (Qamar et al. 2015). Although the P5CDH gene is involved in proline degradation, a high positive correlation between proline accumulation and the relative expression of $P 5 C D H$ under salinity for both genotypes was observed in this study. For BRS Bojuru (tolerant), this high correlation is explained by the same pattern of response between the two variables, at 6, 24 and $72 \mathrm{~h}$ and decrease at $48 \mathrm{~h}$ stress. For BRS Pampa (sensitive), the correlation was due to the observed increase at 6 and $24 \mathrm{~h}$ in the proline content and expression of $P 5 C D H$ and the difference between these variables after 48 and $72 \mathrm{~h}$ (Fig. 2b, d). On the other hand, under cold stress, there was no significant correlation between $P 5 C D H$ and proline content for either genotype (Fig. 6a, b).

In many cases, the mRNA level of a gene does not follow the level of protein activity encoded by it, due to mechanisms of post-transcriptional regulation and/or posttranslational modifications. In a study by Qamar et al. (2015), the P5CDH gene was post-transcriptionally downregulated by siRNAs under salt stress. The proline catabolism generates the byproduct $\mathrm{H}_{2} \mathrm{O}_{2}$, thus activating the antioxidant signaling pathways (Zhang and Becker 2015). However, there are lines of research that state that P5C metabolism in the mitochondria increases the production of reactive oxygen species (ROS) in excess, leading to cell death (Nishimura et al. 2012).

One of the arginine hydrolysis products is arginine conversion to ornithine by the enzyme arginase (ARG), which is metabolized by the enzyme ornithine delta 
aminotransferase or ornithine aminotransferase (OAT) to $\mathrm{P} 5 \mathrm{C}$, this to GSA and then to glutamate. The direct contribution of OAT for proline accumulation induced by stress is controversial (Winter et al. 2015). In the experimental conditions, there was a positive correlation between proline content and expression of the $O A T$ gene in the tolerant genotype, while sensitive to the correlation was positive, but low, under salt stress. Moreover, under cold $\left(13{ }^{\circ} \mathrm{C}\right)$, there was no correlation between these variables for the tolerant genotype negative correlation for the sensitive (Figs. 5, 6). Roosens et al. (2002) hypothesized that OAT plays an important role in proline accumulation during osmotic stress, which was proved in Arabidopsis thaliana plants by a positive correlation between the increase in free proline content, enzyme activity of OAT, and mRNA levels of the $O A T$ gene in seedlings under salt stress. This hypothesis was reinforced by analysis of transgenic A. thaliana plants that overexpressed OAT, synthesizing more proline than the wild plants under osmotic stress (Roosens et al. 1998, 2002). In the same sense, the overexpression of $O A T$ in rice (Oryza sativa L.) resulted in higher proline levels and activated the antioxidant defense, making the plants more tolerant to $\mathrm{NaCl}$ stress (You et al. 2012). However, more research is needed to understand how OAT contributes to increase free proline and whether the GSA produced by OAT can be used directly for proline synthesis or if it is compulsorily converted to glutamate by P5CDH (Winter et al. 2015).

\section{Conclusions}

From the results, it was concluded that: (1) the increase in proline content is highest in BRS Bojuru (tolerant) under the two tested stresses and (2) under salt stress, the transcripts levels of biosynthesis genes are more correlated to proline content in the tolerant genotype, while under cold, the correlation was higher for the sensitive genotype (BRS Pampa).

Author contribution statement Conceived and designed the experiments LCB and EJBB. Wrote, edited, and analyzed the data: LCB, ILV, PAA, MNA, GPM, and GSR. Revised the paper: LCB, LCM, AMMJ, and EJBB conducted the experiments: LCB, ILV, PAA, MNA, GPM, and GSR. All authors readed the paper and approved the final manuscript.

Acknowledgements This work was supported by the Brazilian funding agency Coordenação de Aperfeiçoamento de Pessoal de Nível Superior (CAPES), Fundação de Amparo a Pesquisa do Rio Grande do Sul (FAPERGS) and Conselho Nacional de Desenvolvimento Científico e Tecnológico (CNPq).
Compliance with ethical standards

Conflict of interest The authors declare that they have no competing interests.

\section{References}

Anderson L, Seilhamer J (1997) A comparasion of selected mRNA and protein abundances in human liver. Electrophoresis 18:533-537

Ashraf M, Akram NA, Alqurainy F, Foolad MR (2011) Drought tolerance: roles of organic osmolytes, growth regulators, and mineral nutrients. Adv Agron 111:249-296

Bates LS, Waldren RP, Teare ID (1973) Rapid determination of free proline for waterstress studies. Plant Soil 39:205-207

Bhaskara GB, Yang T-H, Verslues PE (2015) Dynamic proline metabolism: importance and regulation in water limited environments. Front Plant Sci 6:484

Cruz RP, Sperotto RA, Cargnelutti D, Adamski JM, Terra TF, Fett JP (2013) Avoiding damage and achieving cold tolerance in rice plants. Food Energy Secur 2:96-119

Fariduddin Q, Varshney P, Yusuf M, Ahmad A (2013) Polyamines: potent modulators of plant responses to stress. J Plant Interact $8: 1-16$

Giberti S, Funck D, Forlani G (2014) $\Delta$ 1-pyrroline-5-carboxylate reductase from Arabidopsis thaliana: stimulation or inhibition by chloride ions and feedback regulation by proline dependo whether NADPH or NADH acts as cosubstrate. New Phytol 202:911-919

Hien DT, Jacobs M, Angenon G, Hermans C, Thu TT, Son LV, Roosens NH (2003) Proline accumulation and D1-pyrroline-5carboxylate synthetase gene properties in three rice cultivars differing in salinity and drought tolerance. Plant Sci 165:1059-1068

Hur J, Jung KH, Lee CH, An G (2004) Stress-inducible OsP5CS2 gene is essential for salt and cold tolerance in rice. Plant Sci 167:417-426

Kavikishor PB, Himakumari P, Sunita M, Sreenivasulu N (2015) Role of proline in cell wall synthesis and plant development and its implications in plant ontogeny. Front Plant Sci 6:544

Li H, Guo H, Zhang X, Fu J (2014) Expression profiles of Pr5CS1 and Pr5CS2 genes and proline accumulation under salinity stress in perennial ryegrass (Lolium perenne L.). Plant Breed 133:243-249

Livack KJ, Schmittgen TD (2001) Analysis of relative gene expression data using real-time quantitative PCR and the 2- $\Delta \Delta C T$ method. Methods 25:402-408

Marijuan MP, Bosch SM (2013) Ecophysiology of invasive plants: osmotic adjustment and antioxidants. Trends Plant Sci 18:660-666

Monteiro JG, Cruz FJR, Nardin MB, Santos DMM (2014) Growth and proline content in pigeon pea seedlings subjected to osmotic stress and to exogenous putrescine. Pesqui Agropecu Bras 49:18-25

Moraes GP, Benitez LC, do Amaral MN, Vighi IL, Auler PA, da Maia LC, Bianchi VJ, Braga EJB (2015) Evaluation of reference genes for RT-qPCR studies in the leaves of rice seedlings under salt stress. Genet Mol Res 14:2384-2398

Nishimura A, Nasano R, Takagi H (2012) The proline metabolism intermediate $\Delta 1$-pyrroline-5-carboxylate directly inhibits the mitochondrial respiration in budding yeast. FEBS Lett 586:2411-2416 
Qamar A, Mysore KS, Senthil-Kumar M (2015) Role of proline and pyrroline-5-carboxylate metabolism in plant defense against invading pathogens. Front Plant Sci 6:503

Qin J, Ma X, Tang Z, Meng Y (2015) Construction of regulatory networks mediated by small RNAs responsive to abiotic stresses in rice (Oryza sativa). Comput Biol Chem 58:69-80

Ribarits A, Abdullaev A, Tashpulatov A, Richter A, Heberle-Bors E, Touraev A (2007) Two tobacco proline dehydrogenases are differentially regulated and play a role in early plant development. Planta 225:1313-1324

Roosens NH, Thu TT, Iskandar HM, Jacobs M (1998) Isolation of the ornithine delta-aminotransferase cDNA and effect of salt stress on its expression in Arabidopsis thaliana. Plant Physiol 117:263-271

Roosens NH, Al Bitar F, Loenders K, Angenon G, Jacobs M (2002) Overexpression of ornithine- $\delta$-aminotransferase increases proline biosynthesis and confers osmotolerance in transgenic plants. Mol Breed 9:73-80

Satoh R, Nakashima K, Seki M, Shinozaki K, Yamaguchi-Shinozaki K (2002) ACTCAT, a novel cis-acting element for proline- and hypoosmolarity-responsive expression of the ProDH gene encoding proline dehydrogenase in Arabidopsis. Plant Physiol 130:709-719

Silva-Ortega CO, Ochoa-Alfaro AE, Reyes-Agüero JA, AguadoSantacruz GA, Jiménez-Bremont JF (2008) Salt stress increases the expression of $p 5 c s$ gene and induces proline accumulation in cactus pear. Plant Physiol Biochem 46:82-92

Singh RK, Redoña E, Refuerzo L (2010) Varietal improvement for abiotic stress tolerance in crop plants: special reference to salinity in rice. In: Pareek A, Spory SK, Bohnert HJ, Govindjee (eds) Abiotic stress adaptation in plants: physiological, molecular and genomics foundation. Springer, New York, pp 387-415

Sripinyowanich S, Klomsakul P, Boonburapong B, Bangyeekhun T, Asami T, Gu H, Buaboocha T, Chadchawan S (2013) Exogenous ABA induces salt tolerance in indica rice (Oryza sativa L.): the role of $O s P 5 C S 1$ and $O s P 5 C R$ gene expression during salt stress. Environ Exp Bot 86:94-105
Su MXF, Li XY, Ma XJ, Zhao Peng AG, Cheng LQ (2011) Cloning two P5CS genes from bioenergy sorghum and their expression profiles under abiotic stresses and MeJA treatment. Plant Sci 181:652-659

Szabados L, Savouré A (2010) Proline: a multifunctional amino acid. Trends Plant Sci 15:89-97

Székely G, Abrahám E, Cséplo A, Rigó G, Zsigmond L, Csiszár J, Ayaydin F, Strizhov N, Jásik J, Schmelzer E, Koncz C, Szabados L (2008) Duplicated P5CS genes of Arabidopsis play distinct roles in stress regulation and developmental control of proline biosynthesis. Plant J 53:11-28

Theocharis A, Clément C, Barka EA (2012) Physiological and molecular changes in plants grown at low temperatures. Planta 235:1091-1105

Thiery L, Leprince A-S, Lefebvre D, Ghars MA, Debarbieux E, Savouré A (2004) Phospholipase D is a negative regulator of proline biosynthesis in Arabidopsis thaliana. J Biol Chem 279:14812-14818

Verbruggen N, Hermans C (2008) Proline accumulation in plants: a review. Amino Acids 35:753-759

Winter G, Todd CD, Trovato M, Forlani G, Funck D (2015) Physiological implications of arginine metabolism in plants. Front Plant Sci 6:534

Xue X, Liu A, Hua X (2009) Proline accumulation and transcriptional regulation of proline biosynthesis and degradation in Brassica napus. BMB Rep 42:28-34

Yamaguchi-Shinozaki K, Shinozaki K (2006) Transcriptional regulatory networks in cellular responses and tolerance to dehydration and cold stresses. Annu Rev Plant Biol 57:781-803

Yoshida S, Forno DA, Cock JH, Gomez KA (1976) Laboratory manual for physiological studies of rice, 3rd edn. International Rice Research Institutes, Manila, p 61

You J, Hu H, Xiong L (2012) An ornithine $\delta$-aminotransferase 1 gene OsOAT confers drought and oxidative stress tolerance in rice. Plant Sci 197:59-69

Zhang L, Becker D (2015) Connecting proline metabolism and signaling pathways in plant senescence. Front Plant Sci 6:552 